UDC 378.147:331.45

DOI: $10.31470 / 2415-3729-2019-10-58-74$

\title{
Educational and Methodological Support of the Future Mechanical Engineering Specialists Training for the Labour Protection Professional Activity
}

\section{Sofiia Dembitska}

Doctor of Philosophy in Pedagogy (Ph.D), Associate Professor Associate Professor of the Departament of Life Safety and Pedagogy of Safety

Vinnytsia National Technical University

$\triangle 95$, Khmelnytske Highway, Vinnytsia, Ukraine, 21021

E-mail: sofiyadem13@gmail.com

ORCID: 0000-0002-2005-6744

Date of receipt of the article: September 28, 2019 Article accepted for publication: December 02, 2019

Навчально-методичне забезпечення підготовки майбутніх фахівців механічної інженерії до працеохоронної професійної діяльності

\section{Софія Віталіївна Дембіцька}

кандидат педагогічних наук, доцент

доцент кафедри безпеки життєдіяльності та педагогіки безпеки Вінницький національний технічний університет

$\triangle$ Хмельницьке шосе, 95, м. Вінниця, Україна, 21021

Дата надходження статті: 28 вересня 2019 р. Стаття прийнята до друку: 02 грудня 2019 р.

\section{Abstract}

The article is devoted to the substantiation of the directions of improving the educational and methodical support of the future 
mechanical engineering specialists' training for labour protection professional activity.

The aim of the article is to identify areas for improving the educational and methodological support of the future mechanical engineering specialists' training for labour protection professional activity. The author uses such research methods as analysis of scientific literature, generalization, comparison, systematization, abstraction and methods of mathematical statistics.

The benefit of the study is that the ways of improving the educational and methodological support of labour protection disciplines and its structure are defined: the target block (contains the purpose and tasks of a discipline study), the normative block (contains information about the number of credits in the context of classroom and independent work, content modules, structural and logical place of a discipline in the educational training of specialists, etc.), the information block (contains training material in a modular structure), the methodical block (contains the characteristics of forms, methods and tools that provide future mechanical engineering specialists by the labour protection competencies' forming), the control unit (contains materials for determining the level of labour protection competence) and the resource unit. Moreover the directions of improving teaching labour protection disciplines are defined and reflected in the educational and methodological support of the future mechanical engineering specialists' training for labour protection professional activity, they are: motivation provision, individual tasks definition, activation of students' educational activity; and the peculiarities of educational and methodological support of the future mechanical engineering specialists' training for labour protection professional activity are characterized.

Key words: labour protection activities, higher education institutions, mechanical engineering, improvement of the training process, training and methodological support. 


\section{References}

1. Afanasev, A.K. (2010). Formirovanie bazovykh professionalnykh kompetentsiy u studentov tekhnicheskikh vuzov, obuchayushchikhsya po programme podgotovki ofitserov zapasa avtomobilnykh voysk [Formation of the basic professional competencies of technical high schools students enrolled in the program of training reserve automobile troops officers]. Extended abstract of candidate’s thesis. Samara: GOU VPO «Samarskiy gosudarstvennyy tekhnicheskiy universitet» [in Russian].

2. Baydenko, V.I., \& Dzh. van Zantvort (2003). Modernizatsiya professionalnogo obrazovaniya: sovremennyy etap [Modernization of vocational education: the modern stage]. Moskva : Issledovatelskiy tsentr problem kachestva podgotovki spetsialistov [in Russian].

3. Bespalko, V.P., \& Tatur, Yu.G. (1989). Sistemno-metodicheskoe obespechenie uchebno-vospitatelnogo protsessa podgotovki spetsialistov [A systematic and methodical support of the educational process of specialists training]. Moskva : Vysshaya shkola [in Russian].

4. Bukharova, B.D., \& Matveeva, T.A. (2005). Formirovanie elektronnogo portfelya studenta tekhnicheskogo vuza kak uslovie stanovleniya ego professionalnoy kompetentnosti [Formation of the electronic portfolio of a technical college student as a condition for its professional competence formation]. Professionalnoe obrazovanie. Prilozhenie "Pedagogicheskaya nauka - praktike. Novye issledovaniya» - Vocational education. Appendix «Pedagogical Science is for Practice. New research», 2, 48-52 [in Russian].

5. Vasileva, Ye.I. (2010). Motivatsiya professionalnoy deyatelnosti gosudarstvennykh grazhdanskikh sluzhashchikh [Motivation of professional work of state civil workers]. Extended abstract of candidate's thesis. Yekaterinburg: Uralskaya akademiya gosudarstvennoy sluzhby [in Russian].

6. Hlyniana, N.M., \& Dementii, L.V. (2004). Orhanizatsiia samostiinoi roboty studenta $z$ dystsypliny "Osnovy okhorony pratsi» $z$ vykorystanniam PEOM [Organization of the student's self-study work on the discipline "Fundamentals of Labour Protection» using the PC]. Kramatorsk : DDMA [in Ukrainian]. 
7. Guzanov, B.N., Kuzina, L.L., \& Shusherin, V.V. (2009). Organizatsiya planirovaniya i kontrolya $\mathrm{v}$ protsesse upravleniya kachestvom obucheniya $\mathrm{v}$ sisteme vysshego professionalnogo obrazovaniya [Organization of planning and control in the management of teaching quality in higher vocational education]. Kachestvo. Innovatsii. Obrazovanie - Quality Innovation Education, 8, 2-8 [in Russian].

8. Dembitska, S.V. (2013). Problemy yakosti znan z okhorony pratsi $\mathrm{v}$ protsesi pidhotovky fakhivtsiv sotsialno-kulturnoi sfery [Problems of the quality of labour protection knowledge in the training process of a social and cultural sphere]. Vyshcha osvita Ukrainy: teoretychnyi ta naukovo-metodychnyi chasopys., Tematychnyi vypusk "Naukovo-metodychni zasady upravlinnia yakistiu osvity $u$ vyshchykh navchalnykh zakladakh» - Higher education in Ukraine: Theoretical and scientific-methodological journal. Thematic issue "Scientific and methodological principles of quality management of education in higher education institutions», 2 (dodatok 2), 99-104 [in Ukrainian].

9. Zhyhir, V.V. (2017). Rozrobka navchalno-metodychnykh kompleksiv vidpovidno do vymoh derzhavnykh osvitnikh standartiv novoho pokolinnia [Development of teaching methods in accordance with the requirements of state educational standards of new generation]. Molod i rynok - Youth and the market, 5 (148), 20-24 [in Ukrainian].

10. Palchevskiy, B.V. (1991). Uchebno-metodicheskiy kompleks sredstv obucheniya [Methodical complex of learning tool]. Sovetskaya pedagogika - Soviet Pedagogy, 6, 26-32 [in Russian].

11. Shalygina, I.V. (2012). Uchebno-metodicheskiy kompleks kak didakticheskiy obekt [Methodical complex as a didactic object]. Otechestvennaya i zarubezhnaya pedagogika-Domestic and foreign pedagogy, 5 (8), 170-177 [in Russian].

12. Anderson, L., Cruikshank, K., Mayer, R., Pintrich, P., Raths, J. \& Wittrock, M. (2001). A taxonomy for learning, teaching, and assessing. New York: David McKay Company. 


\section{Вступ}

Розвиток економіки країни та суспільства в цілому можна забезпечити лише шляхом забезпечення якості освіти. Швидкий розвиток техніки та технологій можливо забезпечити лише тоді, коли на підприємстві є висококваліфіковані фахівці, які і забезпечують такий розвиток. Нині якість підготовки майбутніх фахівців знаходиться в центрі уваги, що пояснюється такими причинами:

- формування загального освітнього і наукового простору Свропи, що вимагає наявності єдиних критерії та стандартів до підготовки фахівців у кожній галузі з метою забезпечення мобільності висококваліфікованих працівників на ринку праці;

- рівень розвитку економіки будь-якої країни, iї становище на світовому ринку в більшій мірі залежить від якості освіти;

- на ринку праці наразі вже наявності диплома недостатньо, необхідно володіти визначеними компетентностями у певній галузі (Дембіцька, 2013).

Враховуючи зазначене, актуальним $є$ обгрунтування шляхів і механізмів оновлення процесу підготовки майбутніх фахівців, пошук ефективних методів та засобів формування фахової компетентності, розробка навчально-методичного забезпечення у відповідності до особливостей компетентнісного підходу у навчанні.

Аналіз досліджень вітчизняних і зарубіжних вчених таких як А. Афанасьев (Афанасьев, 2010), В. Байденко, Дж. ван Зантворт (Байденко \& Зантворт, 2003), В. Беспалько, Ю. Татур (Беспалько, Татур, 1989), Б. Бухарова, Т. Матвеева (Бухарова \& Матвеева, 2005), Е. Васильева (Васильева, 2010), Б. Гузанов, Л. Кузина, В. Шушерин (Гузанов, Кузина \& Шушерин, 2009), Л. Андерсон, К. Гришанк, Р. Майер, П. Пінтріч (Anderson, Cruikshank, Mayer, Pintrich, Raths, \& Wittrock, 2001), показує, що основою вдосконалення процесу професійної підготовки майбутніх фахівців у закладах вищої освіти є розробка та впровадження в навчальний процес навчально-методичного забезпе- 
чення, яке відповідає особливостям компетентнісного підходу. Воно має враховувати інтеграцію традиційних та інноваційних методів, технологій i засобів навчання, міжпредметну інтеграцію та вимоги роботодавців до працівників.

Метою статті $\epsilon$ визначення напрямків вдосконалення навчально-методичного забезпечення підготовки майбутніх фахівців механічної інженерії до працеохоронної професійної діяльності.

\section{Матеріали та методи дослідження}

Під час написання статті були проаналізовані наукові публікації з проблеми дослідження, узагальнено практичні напрацювання та власний педагогічний досвід щодо особливостей формування працеохоронної компетентності студентів технічних спеціальностей. Крім цього, у процесі роботи використанні такі загальні методи досліджень, як узагальнення, порівняння, систематизація та абстрагування. Для визначення ефективності запропонованого навчальнометодичного забезпечення процесу підготовки майбутніх фахівців механічної інженерії до працеохоронної професійної діяльності було використано експертне оцінювання, для опрацювання результатів опитування експертів - методи математичної статистики.

\section{Результати та їх обговорення}

Однією $з$ причин виробничого травматизму $є$ недостатня якість знань працівника, отриманих як на етапі професійної підготовки, так і під час його трудової діяльності. в такій ситуації працівник не може проаналізувати наслідки своєї діяльності, визначити до чого може призвести недотримання правил безпеки під час виробничого процесу.

Формування працеохоронної компетентності як здатності працівника до свідомої безпечної праці має відбуватися ще на етапі підготовки фахівців. Особливу увагу під час цього процесу необхідно приділяти формуванню умінь критично мислити та оцінювати виробничі завдання з погляду безпеки, а 
також сприяти розвитку готовності до дій в нових, спонтанно виникаючих небезпечних виробничих ситуаціях. А тому, на нашу думку, для підвищення якості підготовки у закладах вищої освіти та забезпечення формування працеохоронної компетентності суттєве значення мають:

- методичне дослідження й обгрунтування тем навчальної програми 3 охорони праці iз врахуваннях особливостей підготовки фахівців механічної інженерії;

- використання ефективних нових технологій навчання (дистанційних, комп'ютерних, модульних, кредитномодульних технологій, мультимедіатехнологій) як в автономній формі, так і в поєднанні з традиційною формою навчання (Глиняна \& Дементій, 2004:12);

- здійснення необхідного i якісного контролю рівнів працеохоронної компетентності студентів;

- розробка та систематизація дидактичних засобів навчання, зокрема електронних навчальних посібників, ілюстративних і методичних матеріалів;

- розробка та обгрунтування вимог до професійної компетентності фахівців механічної інженерії безпосередньо 3 питань охорони праці;

- створення автоматизованих навчальних курсів, комп'ютерних програм, автоматизованої системи контролю засвоєних знань.

Все це має бути відображено у відповідному навчальнометодичному забезпеченні, використання якого дозволить впливати на формування працеохоронної компетентності майбутніх фахівців механічної інженерії.

Погоджуємося 3 думкою I. Шалигіної у тому, що навчально-методичне забезпечення $є$ саме тим дороговказом, основне завдання якого - визначення змісту й обсягу вивчення навчальної дисципліни; встановлення вимог до рівня засвоєння змісту дисципліни студентом; визначення змісту та обсягу самостійної роботи студента, форм і засобів контро- 
лю ii виконання; здійснення організаційно-методичного та інформаційного супроводу освітнього процесу (Шалыгина, 2012).

На думку Б. Пальчевського, значення навчальнометодичного забезпечення дисципліни у тому, що це такий набір матеріалів, які відрізняються від стандартних навчальних посібників поглибленим змістом дидактичних і методичних компонентів, що сприяє активізації навчально-пізнавальної діяльності студентів (Пальчевский, 1991:27).

Навчально-методичне забезпечення працеохоронних дисциплін, розроблене нами з метою забезпечення ефективності процесу формування працеохоронної компетентності майбутніх фахівців механічної інженерії містить нормативну і навчально-методичну документацію, засоби навчання і засоби контролю та розроблене і для викладача, і для студентів.

Грунтуючись на результатах наукових пошуків В. Жигірь (Жигірь, 2017), до складу навчально-методичне забезпечення працеохоронних дисциплін ми віднесли:

1) цільовий блок, що містить мету та завдання вивчення певної дисципліни, які $є$ програмою дій для студентів. В нашому випадку - це формування на відповідному рівні працеохоронної компетентності, яке дозволить майбутньому фахівцю механічної інженерії ефективно здійснювати працеохоронну професійну діяльність;

2) нормативний блок, який містить інформацію про освітній ступінь, спеціальність, курс, семестр, кількість кредитів в розрізі аудиторної та самостійної роботи, кількість змістових модулів, форми контролю, структурно-логічне місце дисципліни в навчальному процесі підготовки фахівців, міждисциплінарні зв'язки, перелік компетентностей, як результатів вивчення навчальної дисципліни. Все це відображено нами у робочих програмах працеохоронних дисциплін;

3) інформаційний блок - навчальний матеріал за модульною структурою у вигляді опорного конспекту лекцій, 
матеріалів для проведення лабораторно-практичних занять, самостійної та індивідуальної роботи;

4) методичний блок, який розроблений для викладачів та забезпечує формування працеохоронної компетентності майбутніх фахівців механічної інженерії в процесі вивчення фахових дисциплін. Він містить характеристику форм і методів та засобів, які забезпечують формування працеохоронної компетентності майбутніх фахівців механічної інженерії, інструктивно-методичний матеріал, матеріали самоконтролю, індивідуальні завдання, теми творчих робіт тощо;

5) контрольний блок, який містить матеріали для визначення рівня сформованості працеохоронної компетентності майбутніх фахівців механічної інженерії, як результату підготовки до працеохоронної професійної діяльності. Запитання та завдання для самостійної роботи студентів, контрольні роботи працеохоронних дисциплін тощо;

6) ресурсний блок - основна та додаткова література, електронні та Інтернет-ресурси, матеріально-технічні ресурси (наочність, технічні засоби навчання, електронні та програмні навчальні засоби тощо).

Опанування студентами фахових та працеохоронних дисциплін із використанням розробленого навчальногометодичного забезпечення сприяє цілісному i системному сприйняттю матеріалу, який вивчається, залученню студентів в усі етапи навчального процесу, вибудовування власних освітніх траєкторій, можливості здійснення самоконтролю і самооцінки.

Розроблене нами навчально-методичне забезпечення формування працеохоронної компетентності майбутніх фахівців механічної інженерії, має такі особливості:

1) використання можливостей мультимедійних і проблемних технологій, що інтенсифікує навчальний процес, підвищує мотивацію студентів;

2) залучення студентів в усі етапи навчального процесу (визначення і прийняття цілей, вивчення навчального 
матеріалу, рефлексія, оцінка і самооцінка);

3) структурування навчально-методичного забезпечення формування працеохоронної компетентності на основі блочного підходу індивідуалізує процес навчання, дозволяє студентові змоделювати свою особисту освітню траєкторію;

4) визначення психолого-педагогічних вимог при створенні навчально-методичного забезпечення формування працеохоронної компетентності, наявність зручної навігаційної системи в електронній версії роблять навчальний процес комфортним та орієнтованим на особистість студента;

5) зміст навчально-методичного забезпечення формування працеохоронної компетентності забезпечує міждисциплінарні зв'язки між дисциплінами професійної підготовки майбутніх фахівців механічної інженерії;

6) внесення в комплекс навчально-методичного забезпечення формування працеохоронної компетентності блока контролю дозволяє організувати ефективний зворотний зв'язок, здійснювати контроль і самоконтроль засвоєння знань i сформованості вмінь студентів машинобудівних спеціальностей.

Вважаємо за необхідне відзначити, що використання навчально-методичного забезпечення формування працеохоронної компетентності під час вивчення фахових дисциплін не припускало відмови від традиційних форм організації навчально-пізнавальної діяльності студентів. Як показує досвід, важливе значення має безпосереднє спілкування викладача і студента. Таким чином, за умови взаємного доповнення традиційних методів і засобів навчання та нових освітніх технологій в процесі професійної підготовки майбутніх фахівців забезпечується їх максимальна ефективність. Це сприяє формуванню працеохоронної компетентності майбутніх фахівців механічної інженерії.

Для прикладу наведемо розроблене навчально-методичне забезпечення дисципліни «Безпека життєдіяльності» для підготовки фахівців машинобудівних спеціальностей (рис.1). 


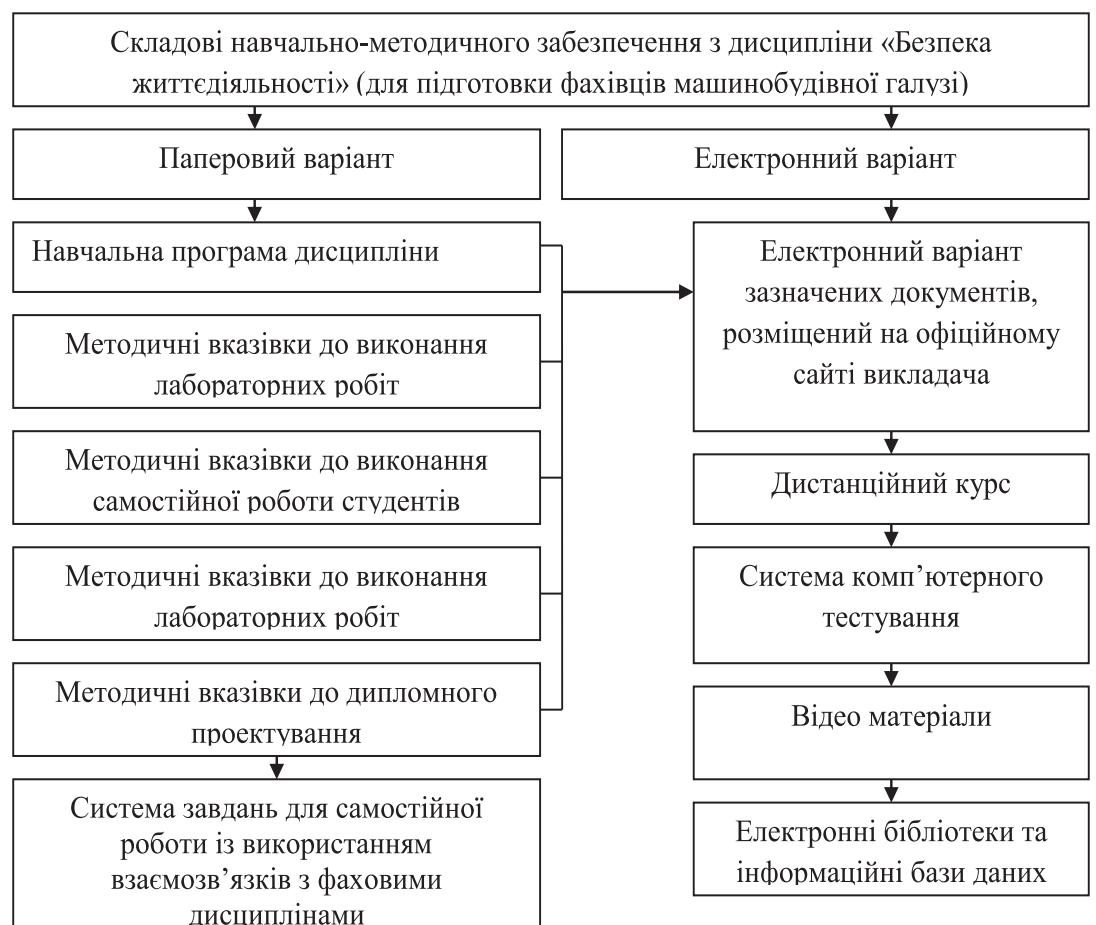

Рис. 1. Структура навчально-методичного забезпечення дисципліни

Для визначення ефективності запропонованого навчальнометодичного забезпечення процесу підготовки майбутніх фахівців механічної інженерії до працеохоронної професійної діяльності було використано експертне оцінювання. Експертами виступили викладачі, які задіяні в процесі фахової підготовки студентів машинобудівних спеціальностей та мають значний досвід і кваліфікацію у цій сфері. До експертного оцінювання були залучені викладачі Вінницького національного технічного університету, Національного авіаційного університету та 
Льотної академії Національного авіаційного університету (всього 21 людина, 3 них 8 докторів та 13 кандидатів наук). За стажем роботи експерти розділилися таким чином (рис. 2):

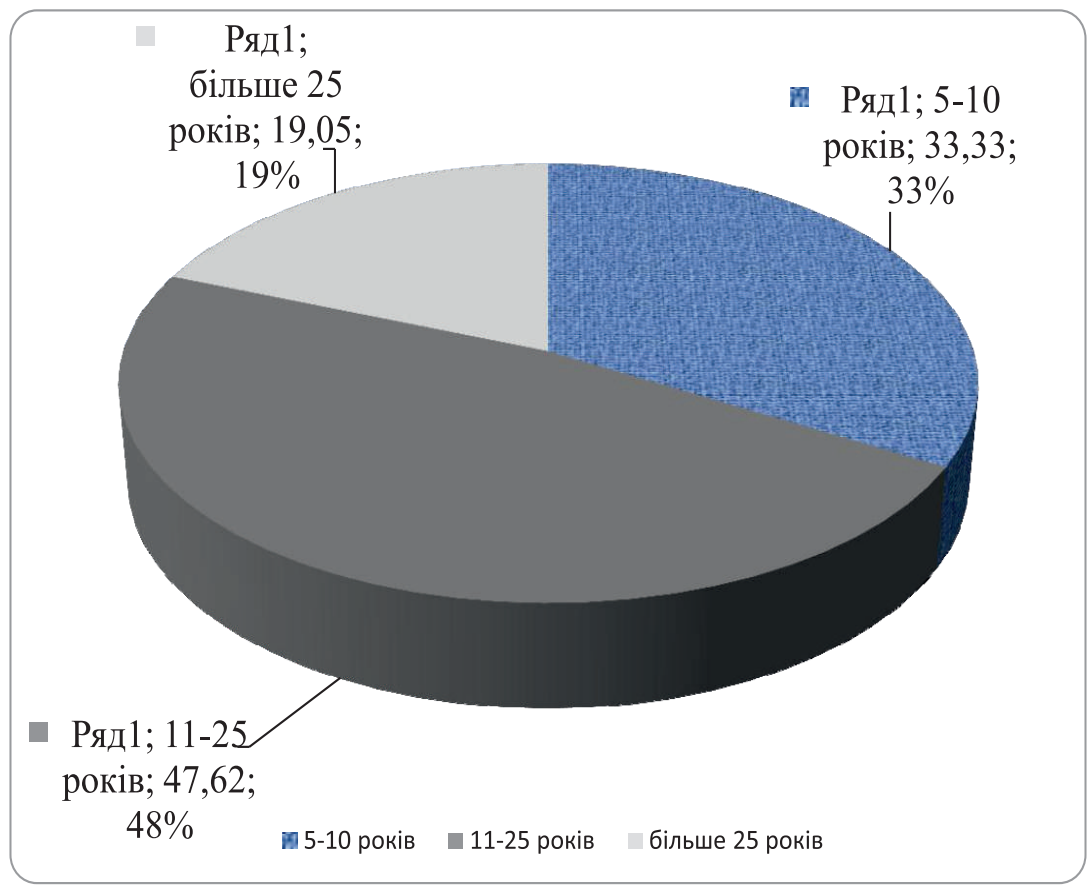

Рис. 2. Розподіл експертів за стажем роботи

- 7 осіб (33,33\%) становлять викладачів 3 досвідом роботи 5-10 років. Як правило, такі викладачі ще не мають виробленого стилю у викладанні, вони готові впроваджувати інновації та проводити експерименти. Перевагою цієї групи є готовність до інновацій, а недоліком - те, що педагогічні експерименти не завжди приводять до позитивного результату;

- 10 осіб (47,62\%) становлять викладачів з досвідом роботи 11-25 років. Це так звана «золота середина», адже вони вже мають напрацьовані ефективні методичні прийоми у викладанні 
дисциплін, перед впровадженням інновацій в педагогічний процес здатні проаналізувати їх та передбачити можливі результати. Однак при цьому вони досить обережно відносяться до педагогічних експериментів;

- 4 особи (19,05\%) становлять викладачів 3 досвідом роботи більше 25 років. Ця група вже має власний педагогічний стиль та у викладанні чітко дотримується роками перевіреного плану. Викладачі цієї групи мають значний досвід практичної та наукової роботи, однак недоліком цієї групи є те, що до педагогічних інновацій у них відношення негативне.

Звичайно, такий поділ є досить умовний. Особливості кожної вікової групи були встановлення шляхом опитування.

Відповіді експертів розподілилися таким чином:

$1.81 \%$ (17 осіб) відмітили позитивно запропоноване навчально-методичне забезпечення процесу підготовки майбутніх фахівців механічної інженерії до працеохоронної професійної діяльності, 19\% (4 особи) - відмітили суттєві, на їхню думку, недоліки. Зокрема, було зазначено, що запропоноване навчально-методичне забезпечення процесу підготовки майбутніх фахівців механічної інженерії до працеохоронної професійної діяльності потребує доопрацювань із врахуванням специфіки конкретних професійних дисциплін. Це є цілком зрозумілим, оскільки запропоноване навчально-методичне забезпечення не $є$ універсальним. Воно $є$ вказівкою для розробки навчально-методичного забезпечення фахових дисциплін та містить рекомендації щодо формування працеохоронної компетентності впродовж усієї професійної підготовки;

2. при уточненні змісту навчально-методичного забезпечення процесу підготовки майбутніх фахівців механічної інженерії до працеохоронної професійної діяльності 71\% (15 осіб) висловили побажання наповнити його практичними прикладами 3 професійної діяльності фахівців машинобудівної галузі. Така робота має бути проведена у співпраці із фахівцями машинобудівної галузі високої кваліфікації; 
3. 76\% (16 осіб) експертів позитивно відмітили запропоновану методику діагностування працеохоронної компетентності майбутніх фахівців механічної інженерії, однак при цьому $87 \%$ (18 осіб) висловили побажання його автоматизувати з метою зменшення часу на визначення рівня працеохоронної компетентності.

\section{Висновки}

Таким чином, можна стверджувати, що результати експертного опитування підтверджують ефективність запропонованого навчально-методичного забезпечення процесу підготовки майбутніх фахівців механічної інженерії до працеохоронної професійної діяльності. При цьому були визначені шляхи його вдосконалення, зокрема:

1. Автоматизувати процес діагностування рівнів працеохоронної компетентності майбутніх фахівців механічної інженерії.

2. Розширити банк проблемних завдань та творчих проектів конкретними завданнями $з$ професійної діяльності працівників машинобудівної галузі.

3. Розробити додаткові дистанційні курси 3 тих питань професійної підготовки, якими найбільше цікавляться студенти.

4. Здійснити порівняльний аналіз працеохоронної професійної діяльності фахівців машинобудівної галузі в Україні та за кордоном. Проаналізувати його позитивні та негативні риси.

\section{Література}

1. Афанасьев А.К. Формирование базовых профессиональных компетенций у студентов технических вузов, обучающихся по программе подготовки офицеров запаса автомобильных войск: автореф. дис. ... канд. пед. наук: 13.00.08 / ГОУ ВПО «Самарский государственный технический университет». Самара, 2010. $21 \mathrm{c}$.

2. Байденко В.И., Дж. ван Зантворт. Модернизация профессионального образования: современный этап. Москва : Ис- 
следовательский центр проблем качества подготовки специалистов, 2003. 674 с.

3. Беспалько В.П., Татур Ю.Г. Системно-методическое обеспечение учебно-воспитательного процесса подготовки специалистов. Москва: Высшая школа, 1989. 141 с.

4. Бухарова Б. Д., Матвеева Т.А. Формирование электронного портфеля студента технического вуза как условие становления его профессиональной компетентности. Профессиональное образование. Приложение «Педагогическая наука - практике. Новые исследования». 2005. №2. С. 48-52.

5. Васильева Е.И. Мотивация профессиональной деятельности государственных гражданских служащих: автореф. дис. ... канд. социол.. наук : 22.00.08 / Уральская академия государственной службы. Екатеринбург, 2010. 20 с.

6. Глиняна Н.М., Дементій Л.В. Організація самостійної роботи студента 3 дисципліни «Основи охорони праці» 3 використанням ПЕОМ. Краматорськ: ДДМА, 2004. 31 с.

7. Гузанов Б.Н., Кузина Л.Л., Шушерин В.В. Организация планирования и контроля в процессе управления качеством обучения в системе высшего профессионального образования. $\mathrm{Ka}$ чество. Инноващии. Образование. 2009. №8. С.2-8.

8. Дембіцька С.В. Проблеми якості знань 3 охорони праці в процесі підготовки фахівців соціально-культурної сфери. Вища освіта Украӥни: теоретичний та науково-методичний часопис., Тематичний випуск «Науково-методичні засади управління якістю освіти у вищих навчальних закладах». 2013. №2 (додаток 2). С. 99-104.

9. Жигірь В.В. Розробка навчально-методичних комплексів відповідно до вимог державних освітніх стандартів нового покоління. Молодь і ринок. 2017. №5 (148). С. 20-24.

10. Пальчевский Б.В. Учебно-методический комплекс средств обучения. Советская педагогика. 1991. №6. С. 26-32.

11. Шалыгина И.В. Учебно-методический комплекс как дидактический объект. Отечественная и зарубежная педагогика. 2012. № 5 (8). С.170-177. 
12. Anderson L., Cruikshank K., Mayer R., Pintrich P., Raths J., Wittrock M. A taxonomy for learning, teaching, and assessing. New York : David McKay Company, 2001. 187 p.

\section{Дембіцька С.B.}

Навчально-методичне забезпечення підготовки майбутніх фахівців механічної інженерії до працеохоронної професійної діяльності

\section{Анотація}

Стаття присвячена обгрунтуванню напрямів вдосконалення навчально-методичного забезпечення підготовки майбутніх фахівців механічної інженерії до працеохоронної професійної діяльності.

Визначені шляхи вдосконалення навчально-методичного забезпечення працеохоронних дисциплін та його структуру (цільовий, нормативний, інформаційний, методичний, контрольний та ресурсний блоки). Схарактеризовані особливості навчально-методичного забезпечення підготовки майбутніх фахівців механічної інженерії до працеохоронної професійної діяльності.

Визначені та відображені у навчально-методичному забезпеченні підготовки майбутніх фахівців механічної інженерії до працеохоронної професійної діяльності напрямки вдосконалення викладання працохоронних дисциплін: забезпечення мотивації, визначення індивідуальних завдань, активізація навчально-пізнавальної діяльності студентів.

Ключові слова: працеохоронна професійна діяльність, заклади вищої освіти, механічна інженерія, вдосконалення процесу професійної підготовки, навчально-методичне забезпечення. 
Дембицкая C.B.

Учебно-методическое обеспечение подготовки будущих специалистов механической инженерии в трудоохранной профессиональной деятельности

\section{Аннотация}

Статья посвящена обоснованию направлений совершенствования учебно-методического обеспечения подготовки будущих специалистов механической инженерии в трудоохранной профессиональной деятельности.

Определены пути совершенствования учебно-методического обеспечения трудоохранных дисциплин и его структуру (целевой, нормативный, информационный, методический, контрольный и ресурсный блоки). Охарактеризованы особенности учебно-методического обеспечения подготовки будущих специалистов механической инженерии в трудоохранной профессиональной деятельности.

Определены и отражены в учебно-методическом обеспечении подготовки будущих специалистов механической инженерии в трудоохранной профессиональной деятельности направления совершенствования преподавания працохоронних дисциплин: обеспечение мотивации, определение индивидуальных задач, активизация учебно-познавательной деятельности студентов.

Ключевые слова: трудоохранная профессиональная деятельность, учреждения высшего образования, механическая инженерия, совершенствование процесса профессиональной подготовки, учебно-методическое обеспечение. 